\title{
ESTIMASI TEMPERATUR BAWAH PERMUKAAN BERDASARKAN KEHADIRAN MINERAL ALTERASI PADA SUMUR "X" LAPANGAN PANAS BUMI WAYANG WINDU, PANGALENGAN, KABUPATEN BANDUNG, PROVINSI JAWA BARAT
}

\author{
SUBSURFACE TEMPERATURE ESTIMATION BASED ON THE PRESENCE OF \\ ALTERATION MINERALS IN "X" WELL OF THE WAYANG WINDU GEOTHERMAL \\ FIELD, PANGALENGAN, BANDUNG REGENCY, WEST JAVA PROVINCE
}

\author{
Vina Oktaviany, Johanes Hutabarat, dan Agus Didit Haryanto \\ Fakultas Teknik Geologi UNPAD, JI. Raya Bandung-Sumedang Km.21, Jatinangor, 45363 \\ vina.oktaviany@gmail.com
}

\begin{abstract}
ABSTRAK
Temperatur merupakan aspek penting dalam sistem panas bumi untuk pengembangan panas bumi sebagai sumber energi. Penelitian ini dimaksudkan untuk mengetahui jenis litologi, mineral alterasi, tipe dan intensitas alterasi serta penyebarannya pada sumur $X$, dan bertujuan menentukan temperatur berdasarkan geotermometer mineral yang kemudian dibandingkan dengan data hasil pengukuran temperatur $(T)$ sumur. Objek dalam penelitian ini berupa serbuk bor (cutting) dari sumur $X$ yang dianalisis dengan metode petrologi, petrografi, dan XRD. Hasilnya menunjukkan, bahwa litologi sumur $X$ terdiri atas andesit terubah, tuf litik terubah, dan tuf kristal terubah. Mineral alterasi yang berkembang didominasi oleh mineral alterasi dengan $\mathrm{pH}$ netral yang berupa kuarsa sekunder, kalsit, epidot, montmorilonit, illit, smektit, klorit, oksida besi, dan pirit, serta beberapa mineral ber-pH asam seperti kaolinit, kristobalit, anhidrit, dan haloysit. Berdasarkan asosiasi mineralnya, alterasi pada sumur $\mathrm{X}$ dibagi menjadi tiga tipe, yaitu alterasi argilik dengan perkiraan temperatur antara $150^{\circ} \mathrm{C}$ hingga $180^{\circ} \mathrm{C}$, alterasi subpropilitik antara $150^{\circ} \mathrm{C}$ s.d. $220^{\circ} \mathrm{C}$, dan alterasi propilitik antara $210^{\circ} \mathrm{C}$ s.d. $280^{\circ} \mathrm{C}$. Secara umum, hasil geotermometer mineral ini menunjukkan data temperatur yang lebih tinggi dibandingkan data T berdasarkan pengukuran sumur.
\end{abstract}

Kata kunci: Tipe alterasi, Serbuk bor, Geotermometer mineral, Wayang Windu, Pangalengan

\begin{abstract}
Temperature is an important aspect in geothermal system to development geothermal as energy resources. The purpose of this research is to know the lithologies, alteration minerals, type and intensity of alteration in $X$ well, and intent to determine the temperature of $X$ well based on mineral geothermometry and compare it with temperature $(T)$ data of well. The object of this research is the cutting sample from $X$ well analyzed by using petrological method, petrographical method and $X R D$. Observation results show those lithologies found in the $X$ well are altered andesite, lithic tuff and crystal tuff. Alteration minerals found are dominated neutral $\mathrm{pH}$ alteration minerals (secondary quartz, calcite, epidote, montmorillonite, illite, smectite, chlorite, iron oxide and pyrite) and acid-neutral $\mathrm{pH}$ alteration minerals (kaolinite, cristobalite, anhydrite and halloysite). Based on it associated minerals, $X$ well is divided into three alteration types : argillic with temperature estimate of about $150^{\circ}-180^{\circ} \mathrm{C}$, subpropylitic about $150^{\circ}-220^{\circ} \mathrm{C}$, and propylitic about $210^{\circ}-280^{\circ} \mathrm{C}$. Generally, the result of geothermometry minerals shows that temperature data are higher than $T$ data of well.
\end{abstract}

Keyword: Alteration Type, Cutting, Geothermometry minerals, Wayang Windu, Pangalengan 


\section{PENDAHULUAN}

Sistem panas bumi terdiri dari sumber panas, reservoir, lapisan penudung, dan fluida panas. Interaksi fluida dan batuan yang terjadi pada sistem panas bumi menghasilkan mineral-mineral alterasi yang dapat dijadikan indikator temperatur sistem tersebut.

Pembentukan mineral alterasi akibat fluida panas (hidrotermal) tergantung pada temperatur, komposisi dan konsentrasi fluida, komposisi batuan asal, permeabilitas, tekanan, dan durasi aktivitas hidrotermal (Browne, 1989). Mineral alterasi yang sering ditemukan pada lingkungan panas bumi antara lain kalsit, klorit, kalsedon, pirit, ilit, smektit, kristobalit, epidot, oksida besi, wairakit, dan kuarsa. Mineral-mineral ini yang akan dilihat dan dianalisis sebagai indikator temperatur sumur.

Penelitian berlokasi di Kecamatan Pangalengan, Kabupaten Bandung, Jawa Barat. Secara geografis, terletak pada 107'34'00"-107'40'00" BT dan 707'00"$7^{\circ} 15^{\prime} 00$ " LS. Lapangan panas bumi Wayang Windu berproduksi sejak tahun 2000 dengan kapasitas produksi yang dihasilkan sebesar 227 MW. Pembangkit listrik ini didukung oleh 22 sumur produksi dan 3 sumur injeksi (Masri dkk., 2015). Sumur $X$ yang menjadi objek penelitian merupakan salah satu sumur yang memproduksi uap panas dan menghasilkan daya listrik yang cukup besar, terletak di bagian utara wilayah kerja panas bumi Wayang Windu, dengan elevasi 2077 mdpl dan kedalaman sekitar 1829 meter kedalaman ukur (mku). Tujuan penelitian ini adalah untuk mengetahui tipe alterasi serta temperatur pembentukan mineral alterasi di bawah permukaan berdasarkan data sayatan tipis dan data $T$ hasil pengukuran, dan juga dapat digunakan untuk memperbarui data temperatur sumur $X$ sebelumnya.

\section{GEOLOGI REGIONAL}

Lapangan Panas Bumi Wayang Windu terletak sekitar $40 \mathrm{~km}$ dari Kota Bandung, Jawa Barat, tepatnya di bagian selatan lereng G. Malabar (gunungapi strato besar berkomposisi andesitik) dan pada rangkaian gunungapi kecil yang membentang ke arah selatan, termasuk $\mathrm{G}$. Bedil, G. Wayang, dan G. Windu (Bogie and Mackenzie, 1998). Batuan yang umum terdapat pada daerah penelitian adalah aliran lava andesitik, breksi aliran, lahar dan piroklastik.

Berdasarkan Peta Geologi Lembar GarutPameungpeuk (Alzwar dkk., 1992), daerah penelitian disusun oleh Andesit WaringinBedil atau Malabar tua (Qwb), Endapan Rempah Lepas Gunungapi Tua TakTeruraikan (Qopu), Batuan gunungapi Malabar-Tilu (Qmt), dan Batuan gunungapi muda (Qyw). Secara struktur, patahan yang ada memiliki kemiringan curam $\left(>80^{\circ}\right)$ dengan arah sekitar $\mathrm{N} 30^{\circ}-40^{\circ} \mathrm{E}$ dan $\mathrm{N} 330^{\circ}-$ $340^{\circ} \mathrm{E}$ (Bogie dkk., 2008). 


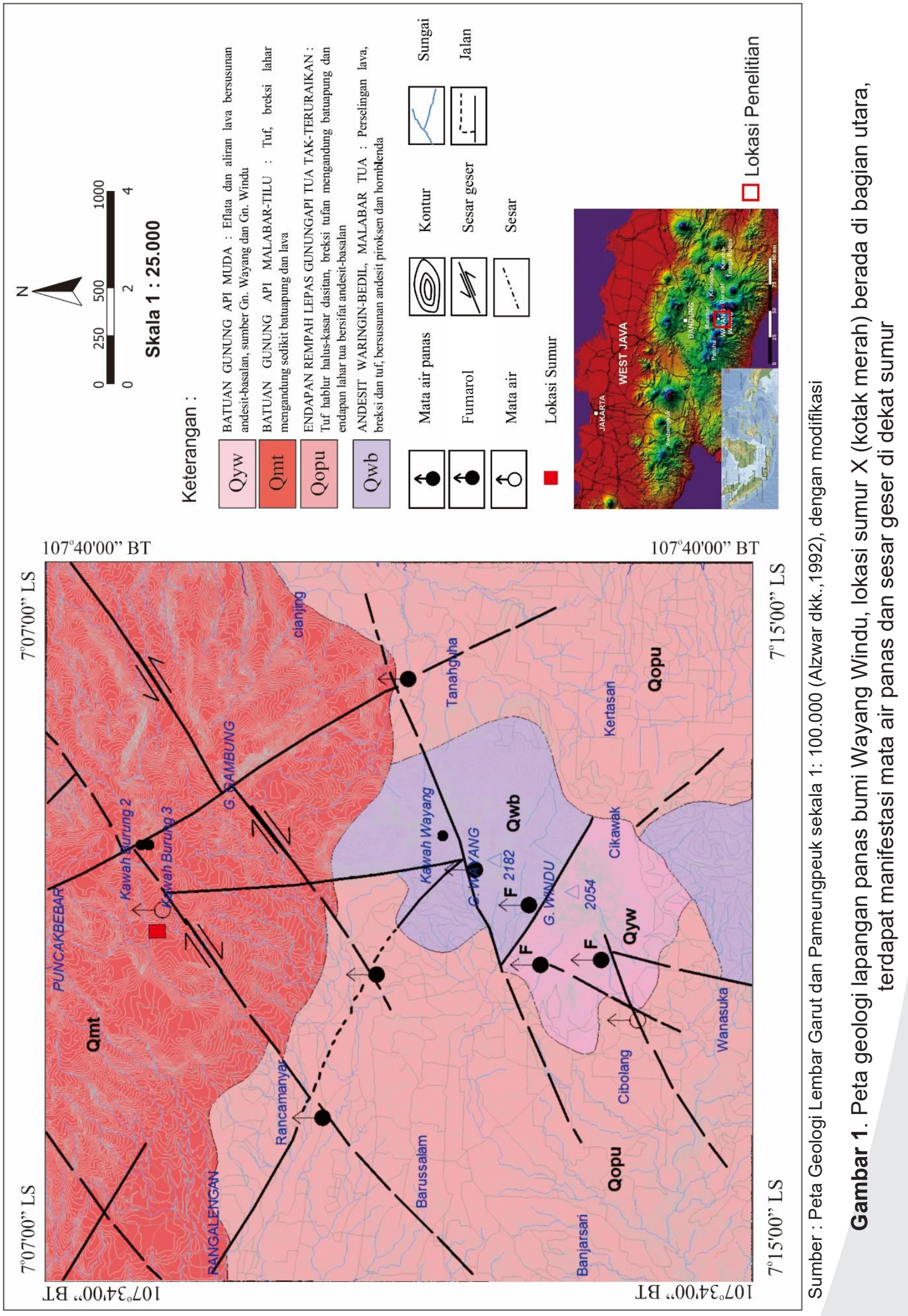




\section{MAKALAH ILMIAH}
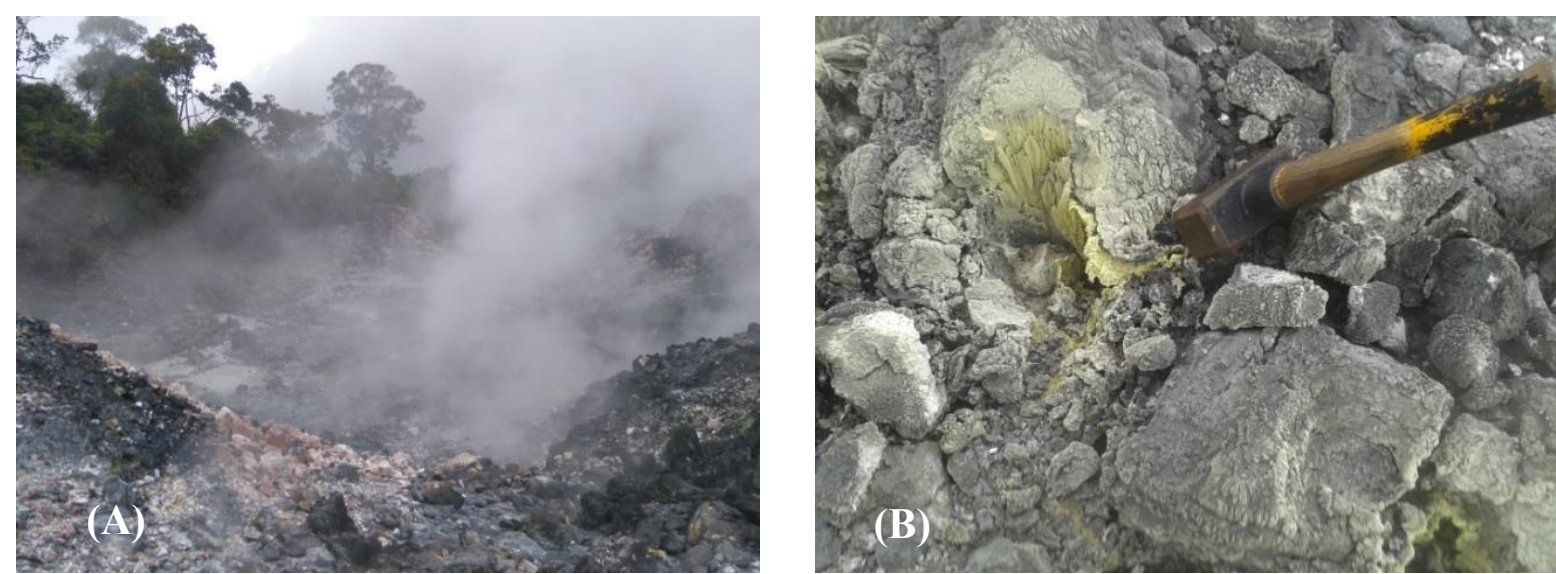

Gambar 2. Manifestasi permukaan yang ditemukan pada Kawah Wayang, berupa (A) Tanah beruap dan (B) Fumarol

\section{MANIFESTASI PERMUKAAN}

Lapangan panas bumi Wayang Windu merupakan transisi antara sistem panas bumi dominasi uap dengan sistem panas bumi dominasi air. Semakin ke selatan, zona dominasi uap semakin menipis dan semakin dalam (Bogie dkk., 2008). Beberapa manifestasi yang ada antara lain mata air panas, fumarol, dan tanah beruap. Manifestasi ini keluar melalui rekahanrekahan terbuka akibat struktur geologi. Sebagian besar mata air panas berjenis air bikarbonat dengan $\mathrm{pH}$ netral dengan kandungan asam sulfat $5 \%$ s.d. $65 \%$ dan memiliki temperatur hingga $66^{\circ} \mathrm{C}$. Fumarola kaya akan sulfat dengan $\mathrm{pH} 1,6$ s.d. 2,77 dan temperatur $56^{\circ} \mathrm{C}$ hingga $93^{\circ} \mathrm{C}$ (Abrenica dkk, 2010). Manifestasi ini dapat ditemukan di beberapa tempat, antara lain Kawah Wayang pada $107^{\circ} 38^{\prime} 13,5^{\prime \prime}$ BT dan $7^{\circ} 12^{\prime} 22,9^{\prime \prime}$ LS, Kawah Burung 2 pada $107^{\circ} 38^{\prime} 8,32^{\prime \prime}$ BT dan $7^{\circ} 9^{\prime} 50^{\prime \prime}$ LS, serta Kawah Burung 3 berada pada $107^{\circ} 38^{\prime} 8,05^{\prime \prime}$ BT dan $7^{\circ} 9^{\prime} 54,18^{\prime \prime}$ LS.

\section{METODOLOGI}

Metode yang dilakukan dalam penelitian yaitu melakukan deskripsi megaskopis terhadap serbuk bor sumur $X$ dari kedalaman 50 mku s.d. 1169 mku meliputi jenis litologi batuan berdasarkan warna, permeabilitas, porositas, persentase mineral mafik dan felsik. Selanjutnya deskripsi terhadap 11 sayatan tipis menggunakan mikroskop polarisasi untuk melihat kandungan mineral primer maupun mineral sekunder pada batuan. Analisis $X$ ray Diffraction (XRD) dilakukan untuk mengidentifikasi mineral yang tidak terlihat dari pengamatan megaskopis ataupun mikroskopis. Hasil analisis ini dibandingkan dengan geotermometer mineral untuk memperkirakan temperatur sumur dan dengan data $\mathrm{T}$ hasil pengukuran sumur yang dilakukan Star Energy Geothermal Indonesia Ltd. untuk melihat adanya kenaikan atau penurunan temperatur sumur $X$. Data $T$ hasil pengukuran ini didapat saat kondisi sumur statis dan telah melalui heating up selama 8 jam.

\section{HASIL DAN PEMBAHASAN}

\section{HASIL}

Litologi pada sumur $\mathrm{X}$ diketahui dari hasil pengamatan dan analisis serbuk bor (cutting), meliputi pengamatan megaskopis dan mikroskopis. Hasil pengamatan megaskopis maupun mikroskopis dari serbuk bor menunjukkan bahwa pada sumur $X$ terdapat tiga jenis litologi, yaitu andesit terubah, tuf litik terubah, dan kristal tuf terubah.

Batuan andesit terubah secara megaskopis berwarna abu-abu hingga abu kehitaman. Pengamatan mikroskopis dilakukan pada sayatan tipis conto kedalaman $821 \mathrm{mku}$ s.d. $824 \mathrm{mku}$. Secara mikroskopis (Gambar 3), batuan berwarna abu-abu, tekstur porfiritik, massa dasar afanitik, 
hipokristalin, memiliki bentuk kristal subhedral-anhedral, hipidiomorf, kemas terbuka. Komposisinya terdiri dari mineral primer yang tersusun atas plagioklas $\pm 30 \%$ dan piroksen $\pm 7 \%$ dalam massa dasar gelas vulkanik $\pm 15 \%$ dan mikrolit plagioklas $\pm 5 \%$. Terdapat mineral klorit sebanyak $\pm 5 \%$ dan mulai muncul mineral epidot $\pm 2 \%$. Mineral sekunder lain diantaranya mineral lempung $\pm 3 \%$, kalsit \pm $7 \%$, kuarsa $\pm 3 \%$, oksida besi $\pm 3 \%$ dan mineral opak $\pm 7 \%$. Intensitas alterasinya lemah sampai sedang.

Tuf litik secara megaskopis berwarna abuabu, abu-abu terang, abu kehijauan hingga putih keabuan. Pengamatan mikroskopis dilakukan pada sayatan tipis conto kedalaman 140 mku s.d. 143 mku. Secara mikroskopis (Gambar 4), batuan berwarna abu-abu kecoklatan, kemas terbuka, bentuk fragmen membundar, memiliki mineral plagioklas $\pm 10 \%$, fragmen batuan beku $\pm 30 \%$ dan batuan piroklastik $\pm 20 \%$ yang terdapat dalam massa dasar gelas vulkanik $\pm 5 \%$ dan mikrolit plagioklas $\pm 3 \%$, sebagian terubah menjadi mineral lempung. Komposisi mineral sekunder tersusun atas kalsit $\pm 5 \%$, kuarsa $\pm 10 \%$, mineral opak $\pm 5 \%$, klorit $\pm 2 \%$, mineral lempung $\pm 7 \%$, dan oksida besi $\pm 3 \%$. Intensitas alterasi pada kedalaman ini sedang sampai kuat.

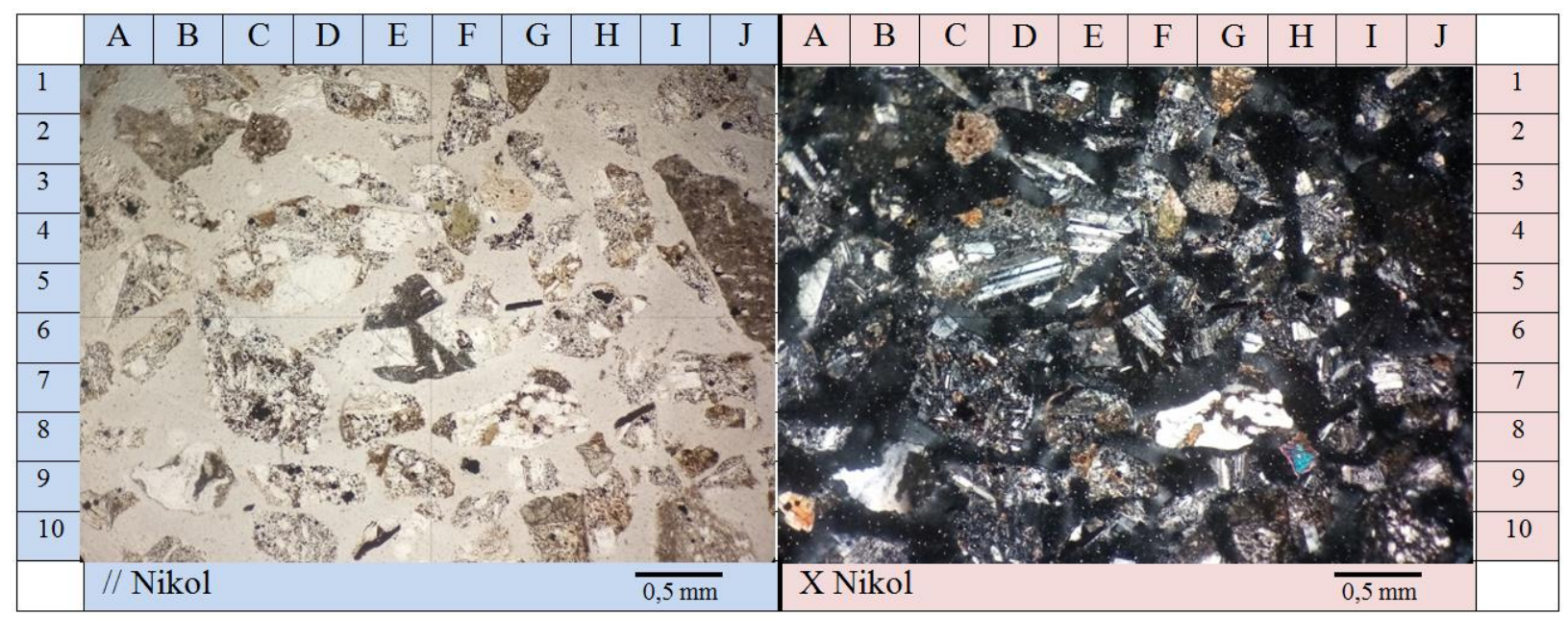

Gambar 3. Sayatan tipis batuan porfiri andesit conto cutting kedalaman 821 mku s.d. 824 mku; terlihat plagioklas (D4), klorit (F4), dan piroksen (H8)

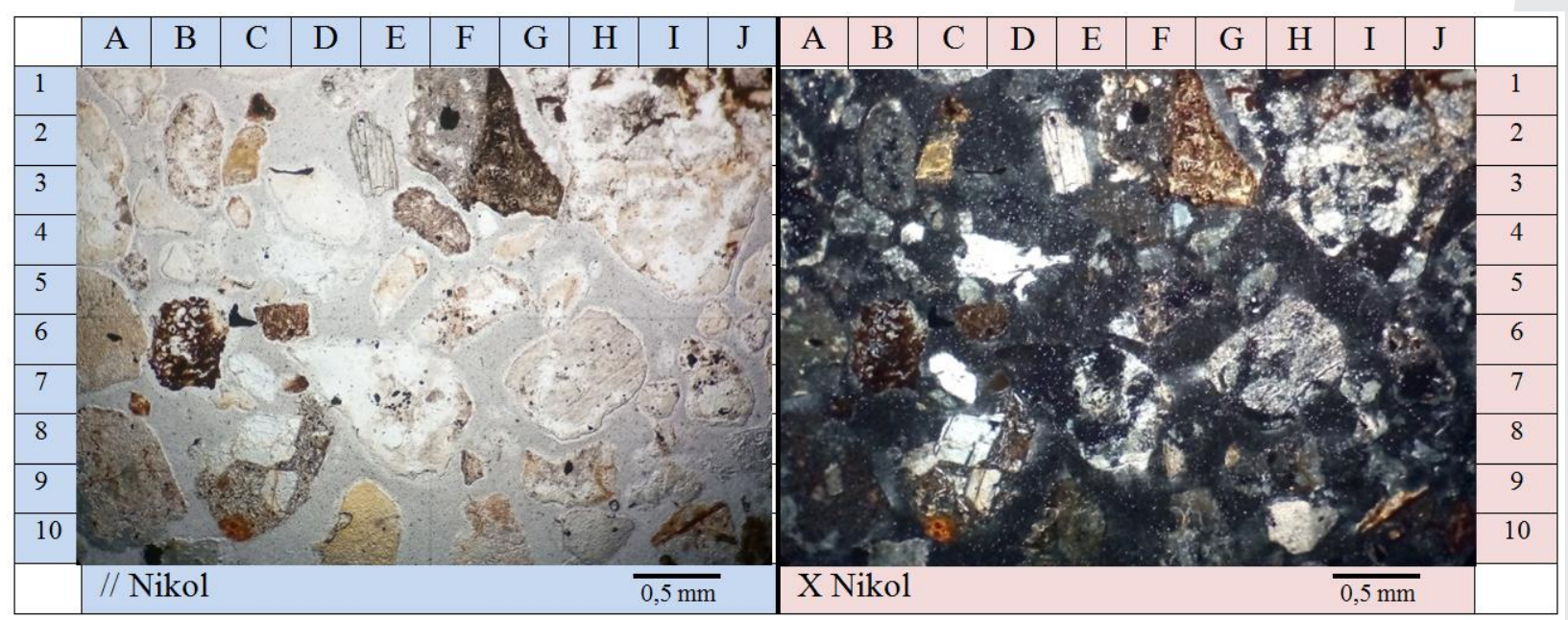

Gambar 4. Sayatan tipis tuf litik conto cutting kedalaman 140-143 mku; terlihat fragmen batuan beku (F1), fragmen piroklastik (D7), oksida besi (B6) 
Tuf kristal secara megaskopis berwarna abu-abu terang hingga abu kehijauan. Pengamatan mikroskopis dilakukan pada sayatan tipis conto kedalaman $944 \mathrm{mku}$ s.d. $947 \mathrm{mku}$. Secara mikroskopis (Gambar 5), batuan berwarna abu-abu, kemas terbuka, bentuk fragmen membundar membundar tanggung. Komposisi mineral tersusun atas plagioklas $\pm 27 \%$ dan piroksen $\pm 5 \%$ di dalam matriks gelas vulkanik $\pm 13 \%$ dan mikrolit plagioklas $\pm 7 \%$ yang sebagian besar telah terubah menjadi mineral lempung. Mineral sekunder lain adalah kalsit $\pm 10 \%$, kuarsa $\pm 15 \%$, klorit $\pm 2 \%$, epidot $\pm 5 \%$ dan mineral opak $\pm 5 \%$. Intensitas alterasi sedang sampai kuat.

Untuk mengidentifikasi mineral alterasi yang sangat kecil, dilakukan analisis XRD pada 3 conto serbuk bor, yaitu kedalaman $320 \mathrm{mku}$ s.d. $323 \mathrm{mku}$ (Gambar 6), kedalaman 710 mku s.d. 713 mku (Gambar 7), dan kedalaman 1070 mku s.d. 1073 mku (Gambar 8).

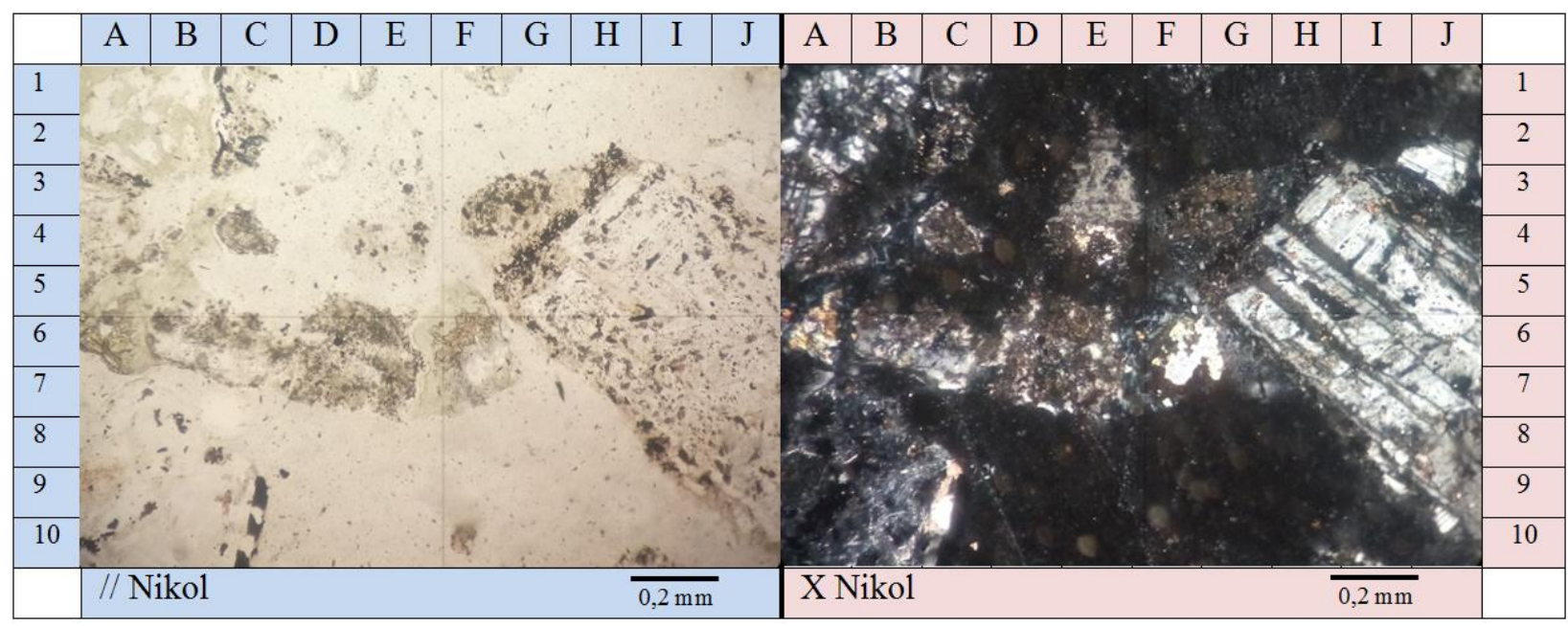

Gambar 5. Sayatan tipis tuf kristal conto cutting kedalaman 944 mku s.d. 947 mku; terlihat epidot (A6), piroksen (I3), plagioklas (I6), kuarsa sekunder (A1) dan kalsit (E4)

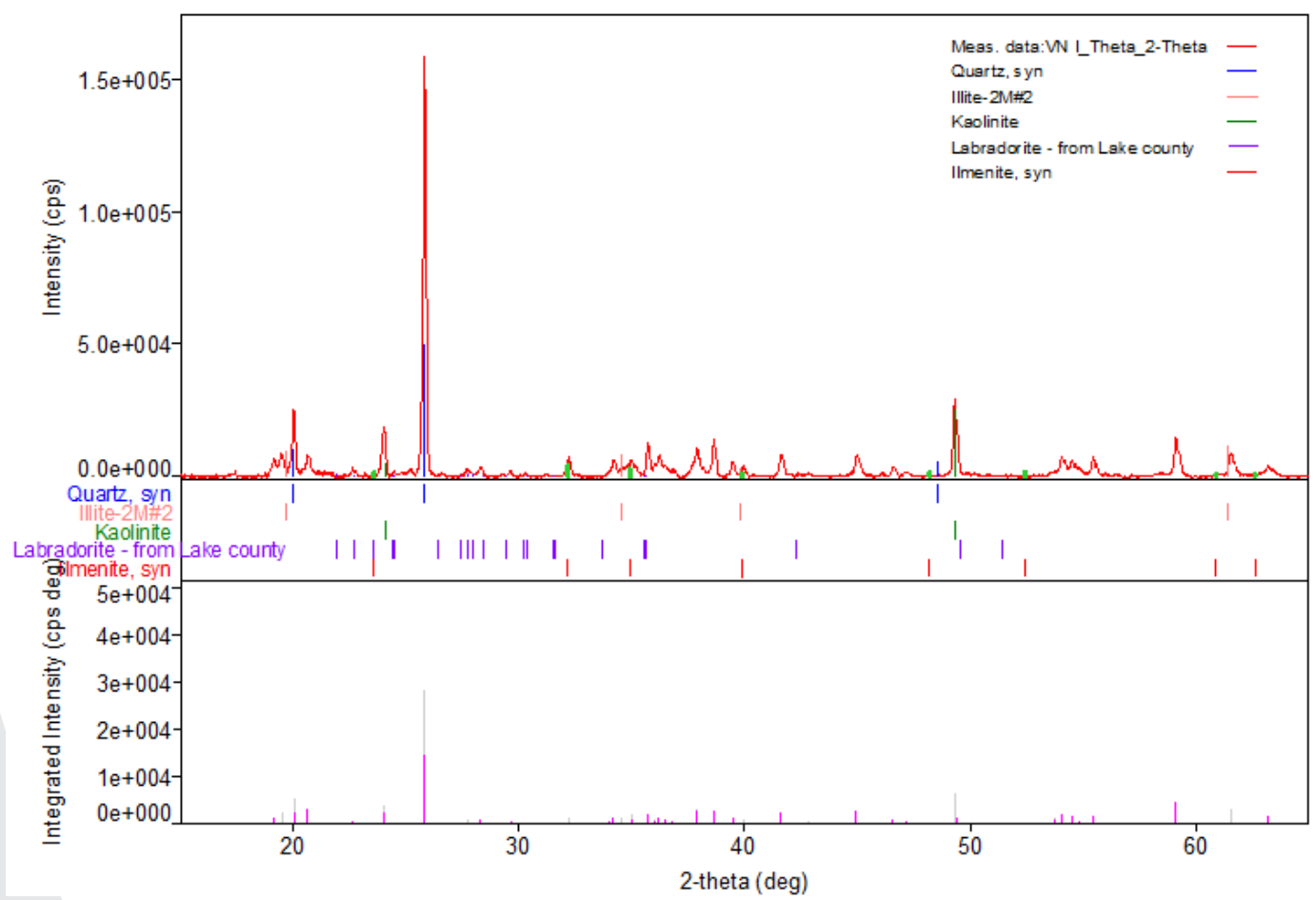

Gambar 6. Data analisis XRD pada conto kedalaman 320 mku s.d. 323 mku, 


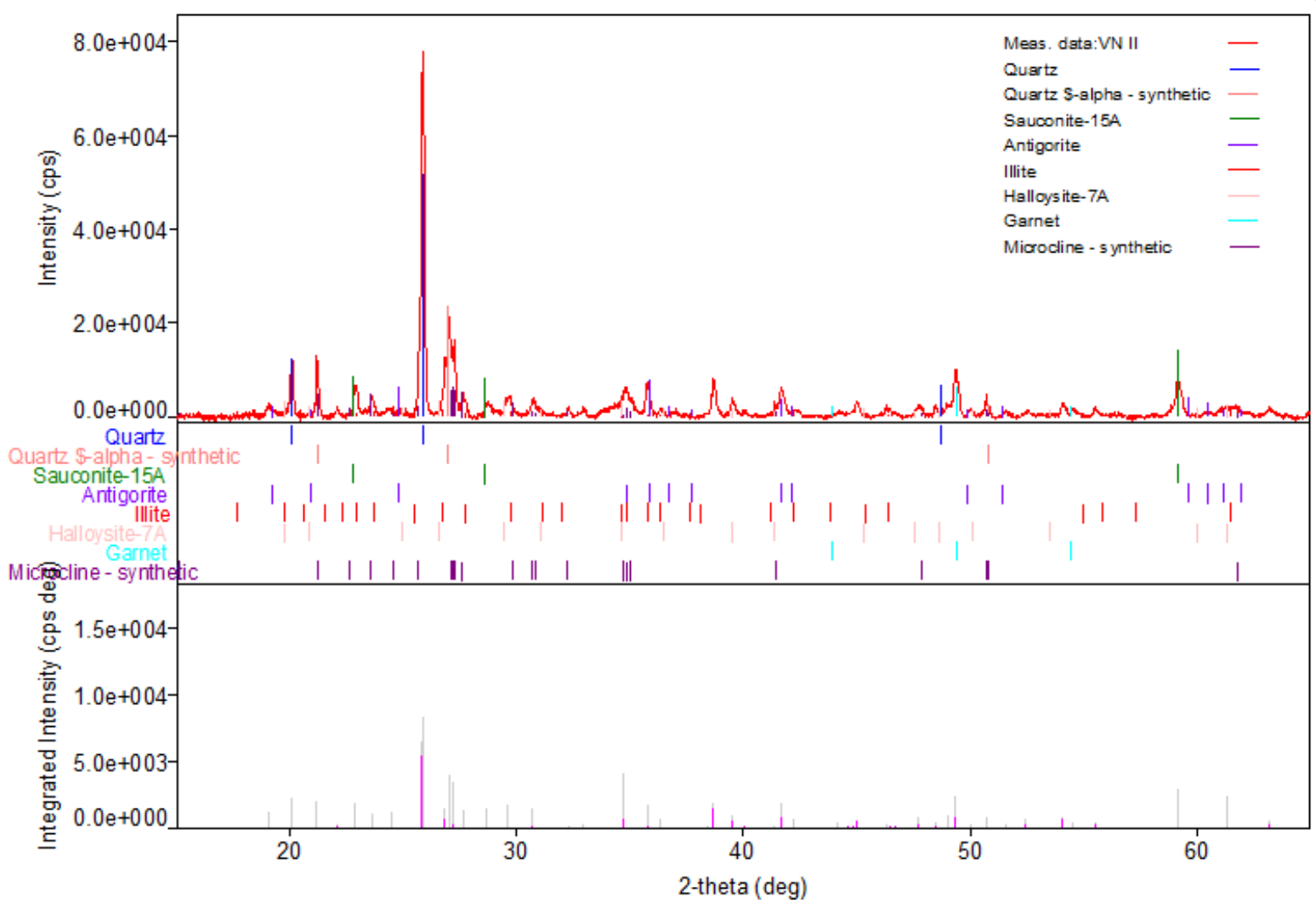

Gambar 7. Data analisis XRD pada conto kedalaman 710 mku s.d. 713 mku, terdapat peak dari mineral kuarsa, ilit dan haloysit

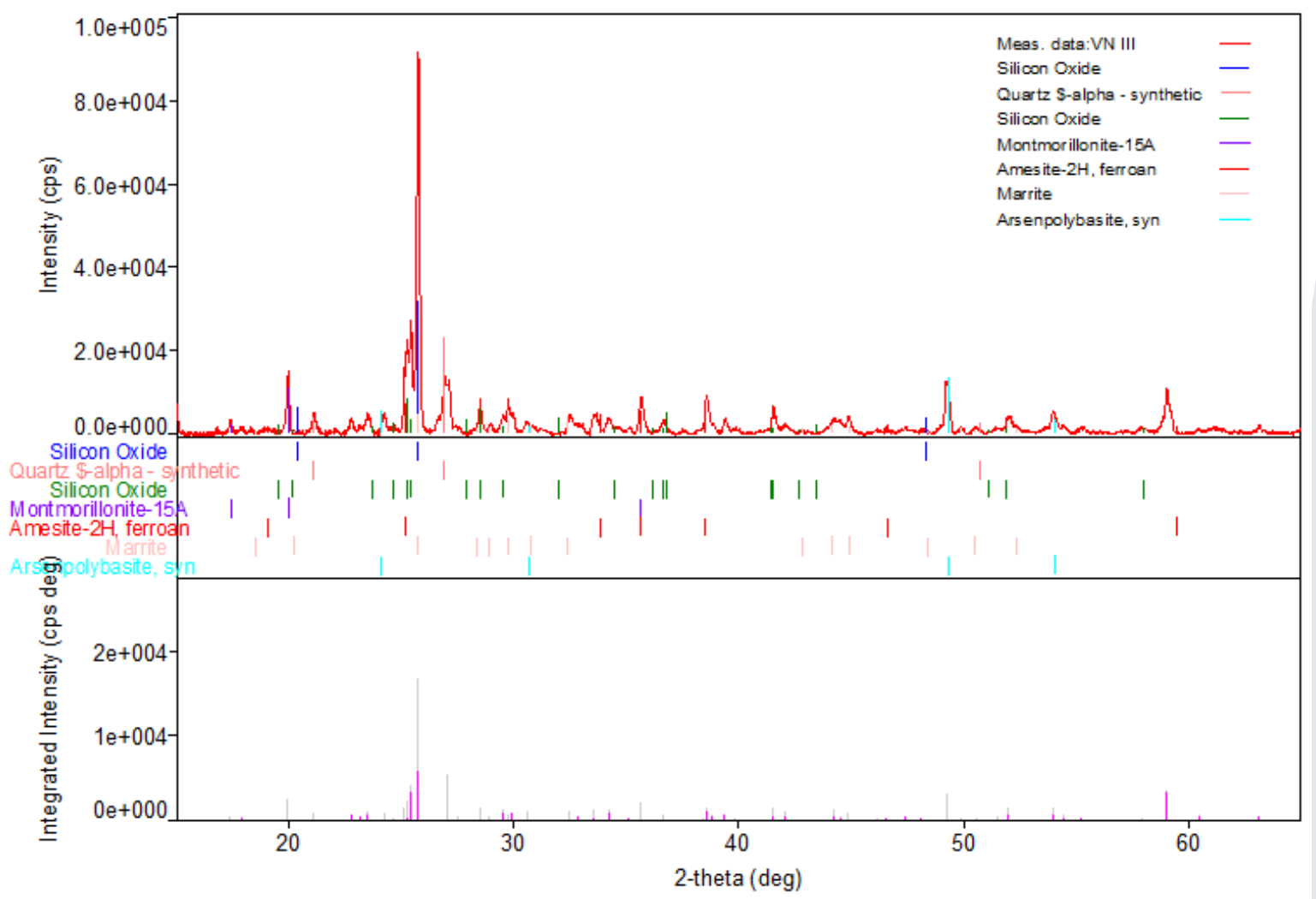

Gambar 8. Data analisis XRD pada conto kedalaman 1070 mku s.d. 1073 mku, terdapat peak dari mineral kuarsa, oksida besi dan montmorilonit 
Hasil analisis megaskopis, mikroskopis dan XRD dari conto serbuk bor serta analisis temperatur sumur, ditampilkan dalam log komposit sumur (Gambar 9) untuk memperkirakan keadaan bawah permukaan sumur X. Log komposit sumur ini memberikan informasi mengenai kedalaman sumur, jenis litologi, keterdapatan mineral sekunder, intensitas alterasi pada setiap kedalaman, tipe alterasi, data temperatur sumur, perkiraan temperatur dan $\mathrm{pH}$ pada tiap tipe alterasi. Data tersebut saling berkorelasi satu sama lain sehingga memberikan gambaran tentang sumur $X$.

Dilihat dari log komposit sumur tersebut, sumur $X$ memiliki tiga litologi yang berselang-seling antara andesit, tuf litik, dan tuf kristal. Litologi andesit masih terdapat pada kedalaman hingga $830 \mathrm{mku}$. Semakin besar kedalamannya, kemunculan andesit semakin sedikit dan keberadaan tuf litik semakin banyak.

Pada kolom intensitas alterasi terlihat bahwa pada litologi andesit, tingkat alterasi cenderung lemah hingga sedang, sedangkan pada tuf litik dan tuf kristal menunjukan intensitas alterasi sedang hingga kuat bahkan sangat kuat pada kedalaman besar. Hal ini terjadi karena tuf memiliki gelas vulkanik dan mineral yang mudah terubah serta mudah dilalui oleh larutan hidrotermal. Seiring bertambahnya kedalaman, intensitas alterasi juga semakin meningkat.

Mineral-mineral pada sumur $X$ diperoleh dari hasil analisa mikroskopis dan XRD.
Ada beberapa mineral alterasi yang hadir hampir pada setiap kedalaman, seperti kuarsa, pirit, kalsit dan klorit. Mineral alterasi derajat tinggi seperti epidot hadir pada kedalaman mulai dari 821 mku hingga 1169 mku. Ini menunjukkan bahwa semakin dalam, semakin tinggi pula temperaturnya.

\section{PEMBAHASAN}

Sumur $X$ terletak pada elevasi 2077 mdpl memiliki total kedalaman sekitar 1169 mku. Temperatur bawah permukaan sumur $X$ dapat diperkirakan dari mineral penciri yang memiliki temperatur stabil tertentu serta data tekanan dan temperatur sumur (Masri, 2006). Berdasarkan mineral pencirinya, alterasi sumur $X$ dapat dikelompokkan menjadi 3 tipe, yaitu alterasi argilik, alterasi subpropilitik, dan alterasi propilitik (Corbett dan Leach, 1997).

Tipe alterasi argilik teramati pada kedalaman dangkal, yaitu 50 mku hingga 119 mku. Didominasi oleh mineral lempung dengan kehadiran kuarsa, smektit, mineral opak dan oksida besi dalam jumlah minor. Selain itu, hadir mineral kristobalit yang mengindikasikan bahwa alterasi dipengaruhi oleh fluida $\mathrm{pH}$ asam-netral yang memiliki temperatur $150^{\circ}-180^{\circ} \mathrm{C}$. Tipe alterasi ini memiliki intensitas alterasi lemah. Dari data T hasil pengukuran, suhu pada tipe argilik adalah $<50^{\circ} \mathrm{C}$. Temperatur yang rendah diperkirakan terjadi karena adanya pengaruh air meteorik yang menurunkan suhu di kedalaman dangkal. 


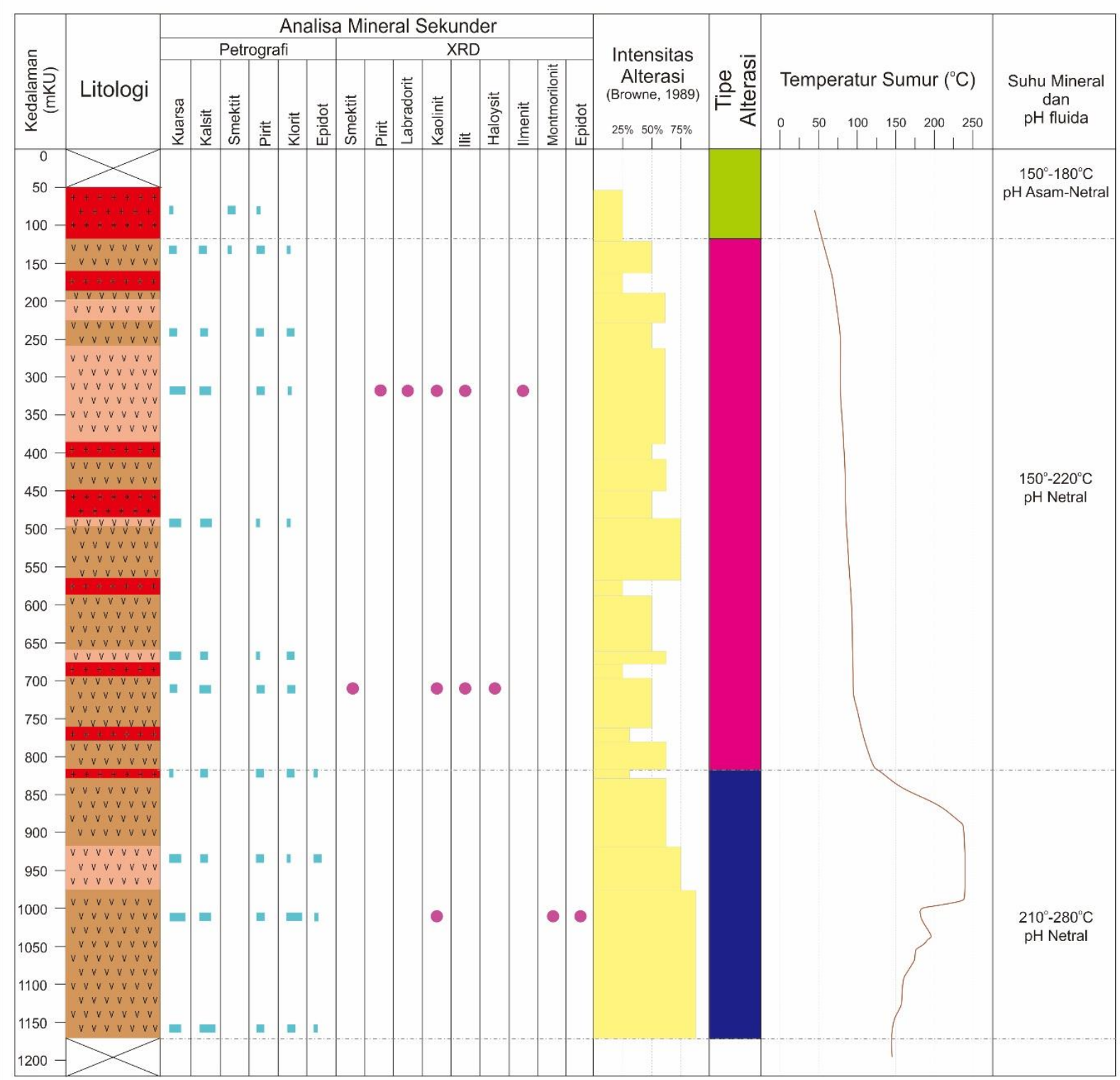

Keterangan :

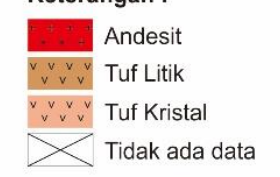

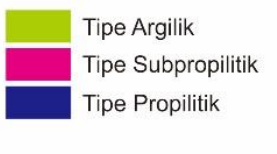

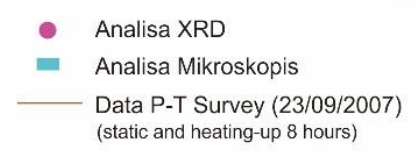

Kelimpahan Mineral :

Intensitas Alterasi :

$$
\begin{array}{ll}
\mid & <5 \% \\
= & 5-10 \% \\
- & 10-15 \% \\
- & 15-25 \%
\end{array}
$$

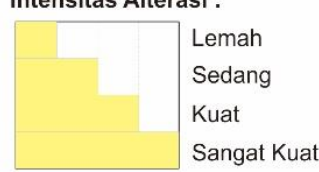

Gambar 9. Log komposit sumur $\mathrm{X}$ yang juga menunjukkan perkiraan temperatur dan $\mathrm{pH}$ pada tiap tipe alterasi

Tipe alterasi subpropilitik terdapat pada kedalaman 119 mku hingga 820 mku. Tipe alterasi ini dapat dijadikan sebagai batuan penudung karena mengandung banyak mineral smektit. Mineral sekunder lain yang hadir adalah klorit, mineral karbonat (kalsit), kuarsa, dan mineral opak (pirit). Pada beberapa conto, hadir mineral anhidrit, kaolinit dan zeolit. Mineral ilit muncul seiring bertambahnya kedalaman.
Adanya kumpulan mineral smektit, klorit, dan anhidrit mengindikasikan bahwa alterasi dipengaruhi oleh fluida yang memiliki temperatur sekitar $150^{\circ} \mathrm{C}$ s.d. $220^{\circ} \mathrm{C}$ dalam kondisi $\mathrm{pH}$ netral. Tingkat intensitas alterasi pada tipe alterasi subpropilitik ini adalah sedang hingga kuat. Berdasarkan data $T$ hasil pengukuran, temperatur pada tipe subpropilitik berkisar $50^{\circ} \mathrm{C}$ s.d. $180^{\circ} \mathrm{C}$, yang artinya terdapat 
penurunan temperatur yang cukup besar terutama pada kedalaman rendah.

\begin{tabular}{|c|c|c|}
\hline \multirow{2}{*}{$\begin{array}{c}\text { Mineral } \\
\text { Geotermometer }\end{array}$} & \multicolumn{2}{|c|}{ Temperatur $\left({ }^{\circ} \mathrm{C}\right)$} \\
\hline & 100 & 200 \\
\hline \multicolumn{3}{|l|}{ Smektit } \\
\hline Kuarsa & & \\
\hline Kristobalit & & \\
\hline
\end{tabular}

Gambar 10. Kisaran temperatur tipe alterasi argilik berdasarkan geotermometer mineral dari mineral smektit, kuarsa, dan kristobalit, yaitu $150^{\circ} \mathrm{C}$ s.d $180^{\circ} \mathrm{C}$ (Hedenquist, 2000)

\begin{tabular}{|c|c|c|}
\hline \multirow{2}{*}{$\begin{array}{c}\text { Mineral } \\
\text { Geotermometer }\end{array}$} & \multicolumn{2}{|c|}{ Temperatur $\left({ }^{\circ} \mathrm{C}\right)$} \\
\hline & 100 & 200 \\
\hline Smektit & & \\
\hline Klorit & & \\
\hline Anhidrit & & \\
\hline
\end{tabular}

Gambar 11. Kisaran temperatur tipe alterasi subpropilitik berdasarkan geotermometer mineral dari mineral smektit, klorit, dan anhidrit, yaitu sekitar $150^{\circ} \mathrm{C}$ s.d. $220^{\circ} \mathrm{C}$ (Hedenquist, 2000)

Tipe alterasi propilitik adalah tipe alterasi yang dapat dijadikan salah satu patokan zona reservoir, terdapat pada kedalaman 820 mku hingga 1169 mku, bahkan bisa lebih dalam. Kehadiran mineral epidot-klorit merupakan ciri utama tipe alterasi ini. Diperkirakan top of reservoir (TOR) berada dekat dengan awal kemunculan epidot pada $821 \mathrm{mku}$. Mineral sekunder lain yang hadir adalah kuarsa, oksida besi, anhidrit, dan mineral opak (pirit). Adanya kumpulan mineral epidot-klorit mengindikasikan bahwa alterasi dipengaruhi oleh fluida yang memiliki temperatur sekitar $210^{\circ} \mathrm{C}$ s.d. $280^{\circ} \mathrm{C}$ dalam kondisi $\mathrm{pH}$ netral. Tipe alterasi propilitik ini memiliki intensitas alterasi sedang-sangat kuat (hampir $100 \%$ ). Dari data T hasil pengukuran, pada kedalaman ini terjadi peningkatan temperatur yang besar dari $180^{\circ} \mathrm{C}$ menjadi maksimum $240^{\circ} \mathrm{C}$. Temperatur ini tidak terlalu berbeda dengan temperatur pembentukan mineral pada kedalaman tersebut. Kedua data menunjukkan adanya temperatur tinggi mulai dari kedalaman sekitar $820 \mathrm{mku}$, hingga bisa diperkirakan zona reservoir dimulai pada kedalaman tersebut.

\begin{tabular}{|c|c|}
\hline Mineral & \multicolumn{2}{|c|}{ Temperatur $\left({ }^{\circ} \mathrm{C}\right)$} \\
\cline { 2 - 3 } Geotermometer & \multicolumn{2}{|c|}{$\mid{ }^{2},{ }^{2}}$, \\
\hline Klorit & \\
Epidot & \\
\hline
\end{tabular}

Gambar 12. Kisaran temperatur tipe alterasi propilitik berdasarkan geotermometer mineral dari mineral klorit dan epidot, yaitu sekitar $210^{\circ} \mathrm{C}$ s.d. $280^{\circ} \mathrm{C}$ (Hedenquist, 2000)

\section{KESIMPULAN}

Secara umum, hasil geotermometer mineral menunjukkan temperatur yang lebih tinggi dibandingkan data $\mathrm{T}$ hasil pengukuran sumur saat kondisi statis. Artinya telah terjadi penurunan temperatur dari awal pembentukan mineral hingga saat pengukuran temperatur sumur oleh perusahaan. Data $T$ hasil pengukuran masih dapat berubah karena pemantauan terus dilakukan secara berkala.

Berdasarkan mineral-mineral yang terdapat pada sumur $\mathrm{X}$, diperkirakan fluida yang membentuknya memiliki $\mathrm{pH}$ asamnetral. Hal ini mengindikasikan fluida tersebut berasal langsung dari reservoir dan sebagian bercampur dengan air magmatik yang cenderung asam.

\section{UCAPAN TERIMA KASIH}

Terima kasih kepada Star Energy Geothermal Indonesia Ltd. yang telah memberikan kesempatan untuk melakukan penelitian di daerah Wayang Windu, Pangalengan, Jawa Barat. Terima kasih disampaikan kepada Tim Editor dan Tim Publikasi Buletin Sumber Daya Geologi yang telah membantu memuat makalah ini. 


\section{DAFTAR PUSTAKA}

Abrenica, A.B., Harijoko, B., Kusumah, Y.I., Bogie, I. 2010. Characteristics of Hydrothermal Alteration in Part of the Northern Vapor-Dominated Reservoir of the Wayang Windu Geothermal Fields, West Java. Proceedings World Geothermal Congress 2010.

Alzwar, M., Akbar, N., Bachri, C. 1992. Peta Lembar Garut-Pameungpeuk, Jawa Barat, Skala 1: 100.000: Pusat Penelitian dan Pengembangan Geologi, Bandung.

Bogie, I., Kusumah, Y.I., Wisnandary. 2008. Overview of the Wayang Windu Geothermal Field, West Java, Indonesia. Amsterdam : Elsevier Scientific Publishing Company, p. 347-365.

Bogie, I., Mackenzie, K. M. 1998. The Application of A Volcanic Facies Model To An Andesitic Stratovolcano Hosted Geothermal, System at Wayang Windu, Java, Indonesia. Proceedings 20th New Zealand Geothermal Workshop, New Zealand.

Browne, P.R.L. 1989. Contrasting Alteration Styles of Andesitic and Rhyolitic Rocks in Geothermal Fields of the Taupo Volcanic Zone.
Proceedings 11th New Zealand Geothermal Workshop, New Zealand.

Corbett, Greg J., Leach, Terry M. 1997. Southwest Pacific Rim Gold-Copper System: Structure, Alteration, and Mineralization. Society of Economic Geologist. Special Publication 6, p. 238.

Hedenquist, J.W., Arribas, A., Jr. Eliseo, G.U. 2000. Exploration for Epithermal Gold Deposits. SEG Reviews, Vol.13, p. $245-277$.

Masri, A., Barton, C., Hartley, L., Ramadhan, Y. 2015. Structural Permeability Assessment Using Geological Structural Model Integrated with 3D Geomechanical Study and Discrete Fracture Network Model in Wayang Windu Geothermal Field, West Java, Indonesia. Proceedings 40th Workshop of Geothermal Reservoir Engineering, Stanford, California.

Masri, A., Hadi, J., Bahar, A., Sihombing, J.M. 2006. Uncertainty Quantification By Using Stochastic Approach in Pore Volume Calculation, Wayang Windu Geothermal Field, W Java, Indonesia. Proceedings 31st Workshop of Geothermal Reservoir Engineering, Stanford, California.

\begin{tabular}{|ll|}
\hline Diterima & $:$ 12 Juli 2017 \\
Direvisi & $:$ 30 Agustus 2017 \\
Disetujui & $:$ 31 Agustus 2017 \\
\hline
\end{tabular}

